\title{
Associations Between Oncogenic Risk Markers and Clinical Outcomes among Black and White Colorectal Cancer Patients
}

\author{
Victoria B. Starks \\ Thomas Jefferson University, victoria.starks@jefferson.edu \\ Edith P. Mitchell, MD, FACP \\ Thomas Jefferson University, Edith.Mitchell@jefferson.edu
}

Follow this and additional works at: https://jdc.jefferson.edu/si_phr_2022_phase1

Part of the Oncology Commons, and the Public Health Commons

Let us know how access to this document benefits you

\section{Recommended Citation}

Starks, Victoria B. and Mitchell, MD, FACP, Edith P., "Associations Between Oncogenic Risk Markers and Clinical Outcomes among Black and White Colorectal Cancer Patients" (2020).

Phase 1. Paper 7.

https://jdc.jefferson.edu/si_phr_2022_phase1/7

This Article is brought to you for free and open access by the Jefferson Digital Commons. The Jefferson Digital Commons is a service of Thomas Jefferson University's Center for Teaching and Learning (CTL). The Commons is a showcase for Jefferson books and journals, peer-reviewed scholarly publications, unique historical collections from the University archives, and teaching tools. The Jefferson Digital Commons allows researchers and interested readers anywhere in the world to learn about and keep up to date with Jefferson scholarship. This article has been accepted for inclusion in Phase 1 by an authorized administrator of the Jefferson Digital Commons. For more information, please contact: JeffersonDigitalCommons@jefferson.edu. 
SI/PHR Abstract

SKMC Class of 2022

Word count: 237

\section{Associations Between Oncogenic Risk Markers and Clinical Outcomes among Black and White Colorectal Cancer Patients \\ Victoria B. Starks, Edith P. Mitchell, MD, FACP*}

Introduction: Blacks have a $25 \%$ higher incidence of colorectal cancer compared to their white societal counterparts. Additionally, the overall mortality rate among black colorectal cancer patients is $50 \%$ higher than that of whites. However, little is known about the biomarkers prevalent among blacks and their possible correlation to treatment response and patient outcomes.

Objective: The objective of this study is to explore disease trends that may unveil a correlation between molecular markers and poor clinical outcomes among black colorectal cancer patients. Methods: De-identified patient data was obtained from The Oncology Data Services Department (Cancer Registry) of TJUH. The population cohort included newly diagnosed colorectal cancer patients treated at TJUH from 2000-2019, and included information regarding patient race, sex, age at presentation, stage at presentation, histological code, tumor markers: KRAS, NRAS, BRAF, MS1, treatment received, surgical findings: tumor size, lymph node involvement, presence of distant metastases at first surgery, response to chemotherapy \& disease-free survival. Results: Preliminary data on the analyzed population demonstrates that biomarker profiles did not correlate with patient race. Therefore, racial disparities seen among colorectal cancer patients cannot be attributed to these findings. 


\section{SI/PHR Abstract}

Conclusion: Biomarker trends among newly diagnosed colorectal cancer patients at TJUH do not correlate with racial identity. Additional data is needed regarding possible etiologies for the comparatively higher incidence and mortality rates among black colorectal cancer patients.

Health professionals should continue to explore possible etiologies for this racial disparity in future studies. 